\title{
Strategi Komunikasi dalam membentuk Budaya Keselamatan kerja melalui Implementasi Observasi PEKA (Pengamatan Keselamatan Kerja) di PT. X
}

\author{
Bambang Sulistyo $\mathbf{P}^{1, *}$ \\ ${ }^{1}$ Fakultas Hukum, Universitas Bhayangkara Jakarta Raya; Jl. Raya Perjuangan, Marga \\ Mulya, Bekasi Utara, Jawa Barat 17121. Telp: 021-88955882, 889955883, e-mail: \\ bambangsp53@yahoo.com, \\ *Korespondensi: e-mail: bambangsp53@yahoo.com,
}

\begin{abstract}
In an effort to establish organizational culture can not be separated from the application of the principles of Communication. In building a culture, surely an organization will carry out a communication process, whereby the Management / Management of the company conveys various policies, responsibilities through messages both verbally and non-verbally continuously to shape the behavior of members of the company organization. For this reason, an appropriate communication strategy is needed, so that company workers can understand, implement, and be affected by messages conveyed and socialized by the Management / Leadership of the organization. As it is known within the organization, it invites organizational members / workers to implement / implement Cultural behavior not easily, so that the communication strategy must be formulated and planned properly, so that it can be used as a reference / guideline in carrying out communication activities. This study seeks to determine the communication strategy implemented in the PT. Pertamina EP HSSE Division in building a Safety and Health culture for all workers / members of the organization. By using the method of observation, carried out on aspects of PEKA (Safety Observation) with the process of Planning, Implementation and evaluation of the Communication Program that is run Based on the observations and evaluations of researchers it can be concluded that communication carried out in the workplace is able to improve unsafe behavior, create dialogue related to safe and unsafe behavior, to safe and unsafe condition and be able to prioritize observations based on the level of risk and subsequently be able to determine the corrective action results from work Safety observations.
\end{abstract}

Keywords: Organization culture, Communication strategy, Safety Observation (PEKA)

\begin{abstract}
Abstrak
Dalam upaya pembentukan Budaya organisasi tidak dapat lepas dari penerapan prinsip-prinsip Komunikasi. Dalam membangun budaya, tentunya sebuah organisasi akan melakukan proses komunikasi, dimana para Manajemen/Pimpinan perusahaan menyampaikan berbagai kebijakan, tanggung jawab melalui pesan baik verbal maupun non verbalsecara terus menerus berkesinambungan untuk membentuk perilaku anggota organisasi perusahaan. Untuk itu diperlukan strategi komunikasi yang tepat, agar para pekerja perusahaan dapat memahami, mengimplementasikan, dan terpengaruh dengan pesan yang disampaikan dan disosialisaikan oleh Manajemen /Pimpinan organisasi .Seperti diketahui didalam organisasi untuk mengajak anggota organisasi / pekerja untuk mengimplementasikan / menerapkan perilaku Budaya tidak mudah, sehingga strategi komunikasi harus dirumuskan dan direncanakan dengan baik, sehingga dapat dipergunakan sebagai acuan/pedoman dalam melaksanakan aktivitas berkomunikasi. Penelitian ini berupaya untuk mengetahui strategi komunikasi yang dilaksanakan di Divisi HSSE PT. X dalam membangun budaya K3 kepada seluruh pekerja/anggota organisasi. Dengan menggunakan metode observasi, dilakukan pada aspek
\end{abstract}


Submitted: 5 Nopember 2019; Revised: 18 Nopember 2019; Accepted: 3 Desember 2019; Published: 25 Januari 2020

PEKA (Pengamatan Keselamatan Kerja) dengan proses Perencanaan, Penerapan/Implementasi dan Evaluasi Program Komunikasi yang dijalankan. Berdasarkan hasil pengamatan dan evaluasi peneliti dapat disimpulkan bahwa komunikasi yang dijalankan ditempat kerja mampu memperbaiki perilaku tidak aman, kondisi tidak aman, menciptakan dialog terkait dengan perilaku aman dan tidak aman, dan kondisi aman dan tidak aman serta mampu memprioritaskan observasi berdasarkan tingkat risiko dan selanjutnya apat menentukan tindakan koreksi hasil observasi dari pengamatan Keselamatan kerja.

Kata Kunci: Budaya organisasi, Strategi Komunikasi, Observasi PEKA

\section{Pendahuluan}

Statistik mengungkapkan bahwa $80 \%$ kecelakaan disebabkan oleh perbuatan yang tidakselamat (unsafe act), dan hanya $20 \%$ olehkondisi yang tidak selamat (unsafe condition). Berdasarkan data dari the Bureau of Labor Statistics Amerika (2007) terdapat kasus sekitar 5 kecelakaan dan penyakit akibat kerja per tahun untuk setiap 100 pekerja (5 kasus /100 pekerja) atau total sekitar 4 juta dollar per tahun. Banyaknya jumlah pekerja yang menderita kecelakaan termasuk penderitaan yang dialami oleh keluargakorban, patut untuk mendapatkan perhatian yang serius dan nyata. Menurut The Occupational Safety and Health Administration (OSHA), untuk mengurangi banyaknya korban kecelakaan kerja di industri, maka kasus kecelakaan harus diletakkan sebagai kasus criminal bisnis yang harus dipertanggungjawabkan oleh pemilik dan manager perusahaan. Setiap jamnya, sedikitnya terjadi satu kasus kecelakaan kerja di Indonesia. Data Departemen Tenaga Kerja dan Transmigrasi menyebutkan bahwa pada tahun 2010 sedikitnya terjadi kasus kecelakaan kerja dimana jumlah ini telah mengalami penurunan bila dibandingkan tahun 2009 sebanyak kasus kecelakaan kerja. Walaupun demikian, kasus kecelakaan kerja di Indonesia masih relative tinggi bila dibandingkan dengan negara lain. Berdasarkan hasil penelitian yang diadakan ILO mengenai standar kecelakaan kerja, Indonesia menempati urutan ke-152 dari 153 negara yang diteliti. Berdasarkan data dari pusat data dan informasi ketenagakerjaan badan penelitian pengembangan dan informasi kementerian ketenagakerjaan republik Indonesia pada triwulan IV tahun 2014 terdapat data kecelakaan di Indonesia sebesar kasus dengan jumlah korban orang. Provinsi Jawa Tengah masuk kedalam peringkat kedua setelah provinsi Jawa timur yaitu jumlah kecelakaan di provinsi Jawatengah sebesar kasus dengan jumlah korban orang. Kecelakaan kerja adalah suatu kejadian yang tidak diduga, tidak dikehendaki dan dapat menyebabkan kerugian baik jiwa maupun harta benda. Kecelakaan kerja dapat menimbulkan kerugian bagi pekerja, pengusaha, pemerintah dan masyarakat sekitarnya. Pada umumnya kecelakaan kerja disebabkan oleh dua factor yaitu manusia dan lingkungan. Faktor manusia yaitu tindakan tidak aman dari manusia seperti sengaja melanggar peraturan keselamatan kerja yang diwajibkan,

Setiap tahun ribuan kecelakaan kerja terjadi di tempat kerja yang menimbulkan kobran jiwa, kerusakan materi, dan gangguan produksi. Secara Global, berdasarkan data dari International Labour Organizations (ILO) bahwa setiap 15 detik seorang pekerja meninggal dunia akibat dari kecelakaan kerja, setiap 15 detik sebanyak 153 pekerja mengalami kecelakaan dan setiap harinya terdapat 6.300 pekerja meninggal dunia akibat kecelakaan kerja. 
International Labour Organization (ILO) memperkirakan sekitar 337 juta kecelakaan kerja terjadi setiap tahunnya yang mengakibatkan sekitar 2,3 juta pekerja kehilangan nyawanya dan pada tahun 2011 terdapat 48.511 kasus kecelakaan kerja seperti bersinggungan dengan benda tajam yang mengakibatkan tergores, tertusuk dan terjatuh. Pada tahun 2007 menurut Jamsostek tercatat 65.474 kecelakaan yang mengakibatkan 1.451 orang meninggal, 5.326 orang cacat tetap, dan 58.697 orang cedera. Data kecelakaan tersebut mencakup seluruh perusahaan yang menjadi anggota Jamsostek dengan jumlah peserta sekitar 7 juta orang atau sekitar $10 \%$ dari seluruh pekerja di Indonesia. Dengan demikian, angka kecelakaan mencapai 930 kejadian untuk setiap 100.000 pekerja setiap tahun.Oleh karena itu jumlah kecelakaan keseluruhannya diperkirakan jauh lebih besar. Bahkan menurut penelitian World Economy Forum tahun 2006, angka kematian akibat kecelakaan di Indonesia mencapai 17-18 untuk setiap 100.000 pekerja.Kerugian materi akibat kecelakaan juga besar seperti kerusakan sarana produksi, biaya pengobatan dan kompensasi. Selama tahun 2007 kompensasi kecelakaan yang dikeluarkan Jamsostek mencapai Rp 165, 95 miliar. Cukup tingginya tingkat angka kecelakaan kerja yang disebabkan oleh perilaku pekerja yang tidak aman (unsafe act) dan kondisi yang tidak aman (unsafe condition) terutama terjadi di perusahaan Migas (Minyak \& Gas) mengakibatkan banyak perusahaan harus mengeluarkan biaya tambahan.

Maksud dan tujuan dari analisis data kecelakaan kerja adalah untuk menemukan dan menentukan faktor-faktor kecelakaan yang terkait dengan peristiwa kecelakaan yang terjadi. Dari hasil analisa dimaksud selanjutnya dapat diambil langkah-langkah untuk mencegah terulangnya kembali kecelakaan serupa, yaitu melalui koreksi terhadap kondisi maupun tindakan yang tidak aman (ILO, 1989). Tujuan statistik dalam penerapan K3 adalah digunakan untuk menilai OHS Performance Program'. Dengan menggunakan statistik dapat memberikan masukan ke manajemen mengenai tingkat kecelakaan kerja serta bebagai faktoryang dapat digunakan sebagai dasar untuk mencegah menurunnya kinerja K3. Adapun tujuan utamanya, yaitu: a). Memperkirakan penyebab dan besarnya permasalahan kecelakaan yang terjadi, b). Mengidentifikasi pencegahan utama yang dibutuhkan, c). Mengevaluasi efektivitas pencegahan yang dilakukan, d). Memonitoring resiko bahaya, peringatan bahaya dan kampanye keselamatan kerja Mencari masukan informasi dari pencegahan yang dilakukan. Salah satu faktor internalyang dapat menentukan keberhasilan kinerja sebuah organisasi bagaimana proses komunikasi dalam melaksanakan hubungan kerja, saling bertukar informasi serta menerapkan kebijakan, norma-norma, prosedur/SOP yang berlaku dalam organisasi.

Industri Minyak dan Gas (MIGAS) dikenal sebagai industri yang padat modal dan berisiko tinggi. Sebagai suatu industri yang berisiko tinggi, dilakukan upaya untuk meningkatkan keselamatan instalasi baik dari segiproses, peralatan dan sumber daya manusianya, sehingga instalasi aman dari gangguan operasi dan dampak terhadap masyarakat sebagai akibat terjadinya suatu keadaan darurat. 
Submitted: 5 Nopember 2019; Revised: 18 Nopember 2019; Accepted: 3 Desember 2019; Published: 25 Januari 2020

Membangun budaya tentu tidak mudah dan dilakukan dalam setiap level pekerja mulai manajemen puncak sampai pekerja terendah. Untuk itu diperlukan suatu perangkat atau sistem pembinaan perilaku. Banyak konsep atau sistem budaya keselamatan dalam perusahaan. Namun belum tentu sesuai dengan kondisi dan budaya local (Ramli, 2010). Atas dasar tersebut telah mengembangkan pendekatan keselamatan berbasis perilaku yang disebut SMART Safety. SMART (Safety Management and Attitude Reinforcement Technique) adalah pendekatan mengelola keselamatan dengan mengintegrasikan aspek manajemen dan pendekatan BBS (Behavior Based Safety). SMART Safety adalah pendekatan K3 dengan menggunakan tiga pilar uatama yaitu, Safety Management System, Operational Safety, and Behavior Safety.

Sedangkan perilaku Keselamatan dan Kesehatan kerja (K3) itu sendiri menurut beberapa penelitian sebelumnya dipengaruhi secara signifikan oleh budaya keselamatan (Safety Culture). Dengan demikian, untuk mengurangi tingkat kecelakaan kerja harus dimulai dengan membentuk budaya keselamatan (Safety Culture) yang baik dalam perusahaan. Aspek situasional dapat diketahui melalui tataran organisasional misalnya Kebijakan, Peraturan, Prosedur, Sistem Manajemen, Komitmen, Kepemimpinan, dan Tanggung jawab pekerja. Komponen perilaku dapat diketahui dengan mengukur melalui pelaporan diri (self report), kecenderungan untuk berperilaku dan observasi terhadap perilaku langsung. Kadangkala perilaku diukur melalui rata-rata terjadinya kecelakaan kerja, insiden yang dianggap sebagai performansi K3, walaupun dianggap kurang pas dibandingkan dengan perilaku aktual, sehingga hanya sebagai sampel dari kondisi sesaat saja. Komponen psikologis secara umum dapat diketahui melalui angket iklim K3, yang akan mengukur norma, nilai, sikap, perilaku dan persepsi setiap pekerja terhadap K3.

Budaya K3 (Safety Culture) adalah Pola perilaku (seperangkat nilai dan norma) keselamatan kerja dari sebagian besar anggota organisasi perusahaan, yang diwujudkan dalam bentuk sikap (saat menentukan keputusan) yang aman (Gunawan, 2013).

Apa itu Budaya Keselamatan, Budaya keselamatan adalah "the way in which safety is managed and perceived in a work place".

Definisi budaya K3 cenderung untuk dipusatkan pada bagaimana pekerja berpikir dan bersikap dari pada bertindak.

Konsep budaya K3 merujuk kepada persepsi terhadap kebijakan, komitmen prosedur/SOP dan penerapannya terkait dengan K3 di tempat kerja. Istilah budaya K3 di sisi lain, merujuk kepada sikap (attitude), keyakinan (belief), dan persepsi dalam kelompok tentang norma dan nilai bersama, dalam rangka bagaimana bereaksi terhadap bahaya dan risiko (risk) serta sistem control / pengawasan dan pengendaliannya terhadap risiko.

Sikap (attitude) digunakan pertama kali oleh Herbert Spencer tahun 1862, yang diartikan sebagai status mental seseorang. La Pierre mendefinisikan sikap sebagai suatu pola perilaku, tendensi atau kesiapan antisipatif, dan predisposisi untuk menyesuaikan dengansituasi sosial, atau secara sederhana sikap adalah respon terhadap stimuli sosial yang 
telah terkondisikan (Azwar, 1995). Sikap adalah cara seseorang melihat 'sesuatu' secara mental (dari dalam diri) yang mengarah pada perilaku yang ditujukan ke orang lain, cara seseorang mengkomunikasikan perasaannya kepada orang lain (melalui perilaku).

Sikap, adalah evaluasi dalam waktu lama tentang yang disukai atau tidak disukai seseorang, perasaan emosional, dan kecenderungan tindakan terhadap beberapa objek atau ide. Sikap menempatkan kita ke dalam kerangka berpikir mengenai menyukai atau tidak menyukai terhadap suatu obyek, bergerak menuju atau beralih darinya. Sikap menuntun kita untuk berperilaku dalam cara yang cukup konsisten terhadap objek yang sama. Karena menghemat energi dan pikiran, sikap sangat sulit diubah.

Sikap adalah pernyataan evaluatif - baik menguntungkan atau tidak menguntungkan tentang objek, orang, atau peristiwa (Robbins \& Coulter, 2007). Sikap mencerminkan bagaimana seseorang merasakan mengenai sesuatu. Ketika seseorang mengatakan bahwa dia menyukai pekerjaannya maka berarti is mengungkapkan sikap tentang pekerjaan. Sikap adalah pengorganisasian terus menerus terhadap motivasi, emosi, persepsi dan proses kognitif dengan menghargai aspek tertentu yang ada di lingkungan (Hawkins \& Motherbaugh, 2010).

Sikap sulit untuk diubah. Sikap seseorang sesuai dalam suatu pola, dan untuk mengubah satu sikap mungkin memerlukan penyesuaian yang sulit untuk lainnya. Dengan demikian, perusahaan biasanya akan berusaha untuk menempatkan produk ke dalam sikap yang sudah ada daripada berusaha untuk mengubah sikap. (Kotler \& Amstrong, 2010). Karakteristik dari sikap adalah sikap relatif konsisten dengan perilaku yang direfleksikan (Schiffman \& Kanuk, 2010)

Sikap adalah suatu proses penilaian yang dilakukan oleh seorang individu terhadap suatu obyek. Berdasarkan beberapa pendapat ahli mengenai sikap, maka dapat disimpulkan bahwa sikap adalah suatu reaksi atau respon berupa penilaian yang muncul dari seorang individu terhadap suatu obyek (Sarlito \& Eko, 2009). Sikap juga dapat dikatakan sebagai suatu perwujudan adanya kesadaran terhadap lingkunganya. Proses yang mengawali terbentuknya sikap adalah adanya obyek disekitar individu memberikan stimulus yang kemudian mengenai alat indra individu, informasi yang yang ditangkap mengenai obyek kemudian diproses di dalam otak dan memunculkan suatureaksi. Penilaian yang muncul, positif atau negatif dipengaruhi oleh informasi sebelumnya, atau pengalaman pribadi individu.

Faktor-faktor pembentuk sikap manusia tidak terbentuk sejak manusia dilahirkan. Sikap manusia terbentuk melalui proses sosial yang terjadi selama hidupnya, dimana individu mendapatkan informasi dan pengalaman. Proses tersebut dapat berlangsung di dalam lingkungan keluarga, sekolah maupun masyarakat. Saat terjadi proses sosial terjadi hubungan timbal balik antara individu dan sekitarnya. Adanya interaksi dan hubungan tersebut kemudian membentuk pola sikap individu dengan sekitarnya. Azwar menguraikan faktor pembentuk sikap yaitu: pengalaman yang kuat, pengaruh orang lain yang dianggap penting, pengaruh kebudayaan, media masa, lembaga pendidikan dan lembaga agama, pengaruh faktoremosional (Azwar, 2010). 
Submitted: 5 Nopember 2019; Revised: 18 Nopember 2019; Accepted: 3 Desember 2019; Published: 25 Januari 2020

Pembentukan sikap (Sarlito dan Eko, 2009) yaitu: 1) pengkondisian klasik, proses pembentukan ini terjadi ketika suatu stimulus atau rangsangan selalu diikuti oleh stimulus yang lain, sehingga rangsangan yang pertama akan menjadi isyarat bagi rangsangan yang kedua. 2) pengondisian instrumental, yaitu apabila proses belajar yang dilakukan menghasilkan sesuatu yang menyenangkan maka perilaku tersebut akan diulang kembali, namun sebaliknya apabila perilaku mendatangkan hasil yang buruk maka perilaku tersebut akan dihindari. 3) belajar melalui pengamatan atau observasi. Proses belajar ini berlangsung dengan cara mengamati orang lain, kemudian dilakukan kegiatan serupa. 4) perbandingan sosial, yaitu membandingkan orang lain untuk mengecek pandangan kita terhadap suatu hal tersebut benar atau salah. Pembentukan sikap seorang individu jugadi pengaruhi oleh adanya interaksi dengan sekitarnya melalui proses yang kompleks.

Faktor-faktor yang mempengaruhi pembentukan sikap seorang individu yang berasal dari faktor internal dan eksternal Gerungan (2004) terdiri dari: a). Faktor internal pembentuk sikap adalah pemilihan terhadap objek yang akan disikapi oleh individu, tidak semua objek yang ada disekitarnya itu disikapi. Objek yang disikapi secara mendalam adalah objek yang sudah melekat dalam diri individu. Individu sebelumnya sudah mendapatkan informasi dan pengalaman mengenai objek, atau objek tersebut merupakan sesuatu yang dibutuhkan, diinginkan atau disenangi oleh individu kemudian hal tersebut dapat menentukan sikap yang muncul, positif maupun negatif. b). Faktor eksternal mencakup dua pokok yang membentuk sikap manusia, yaitu: Interaksi kelompok, pada saat individu berada dalam suatu kelompok pasti akan terjadi interaksi. Masing-masing individu dalam kelompok tersebut mempunyai karakteristik perilaku. Berbagai perbedaan tersebut kemudian memberikan informasi, atau keteladanan yang diikuti sehingga membentuk sikap.

Komunikasi, melalui komunikasi akan memberikan informasi. Informasi dapat memeberikan sugesti, motivasi dan kepercayaan. Informasi yang cenderung diarahkan negatif akan membentuk sikap yang negatif, sedangkan informasi yang memotivasi dan menyenangkan akan menimbulkan perubahan atau pembentukan sikap positif. Jadi, dapat disimpulkan bahwa pembentukan sikap dipengaruhi oleh berbagai faktor, yaitu faktor internal dan eksternal.

Komponen Sikap Sikap yang ditunjukan seorang individu terhadap objek, mempunyai struktur yang terdiri dari beberapa komponen. Komponen dalam struktur sikap (Azwar, 2010) yaitu: a) Komponen Kognitif, Komponen yang berisikan apa yang diyakini dan apa yang dipikir-kan mengenai obyek sikap tertentu - fakta, pengetahuan dan keyakinan tentang obyek terdiri dari: 1) Merupakan representasi apa yang dipercayai oleh individu pemilik sikap. 2) Berisi persepsi, kepercayaan, dan stereotipe yang dimiliki individu mengenai sesuatu (Mann, 1969). 3) Sesuatu yang telah terpolakan dalam fikiran dan 4) Tidak selalu akurat. b) Komponen afektif merupakan komponen yang meliputi perasaan atau emosi seseorang terhadap objek sikap. Komponen afektif pada sikap seseorang dapat dilihat dari perasaan suka, tidak suka, senang atau tidak senang terhadap objek sikap. Afektif, yaitu komponen yang berhubungan dengan 
rasa senang atau tidak senang terhadap objek sikap terdiri dari: 1). Perasaan yang dimiliki terhadap sesuatu. 2). Banyak dipengaruhi oleh kepercayaan atau apa yang kita percayai sebagai benar dan berlaku bagi objek termaksud. c) Komponen perilaku atau konatif, yaitu kecenderungan berperilaku seorang individu terhadap objek yang dihadapinya. Sikap individu perlu diketahui arahnya, negatif atau positif. Untuk mengetahui arah sikap manusia dapat dilihat dari komponen-komponen sikap yang muncul dari seorang individu. Sikap adalah konsep yang dibentuk oleh tiga komponen yaitu kognitif, afektif dan konatif (Sarlito \& Eko, 2009).

Komponen Konatif atau perilaku terdiri dari kesiapan seseorang untu bereaksi atau kecenderungan untuk bertindak terhadap obyek yaitu: 1). Merupakan aspek kecenderungan berperilaku tertentu sesuai dengan sikap yang dimiliki oleh seseorang. 2). Bagaimana orang berperilaku dalam situasi tertentu dan terhadap stimulus tertentu akan banyak ditentukan oleh bagaimana kepercayaan dan perasaannya terhadap stimulus tersebut. 3). Kecenderungan berperilaku belum tentu akan benar-benar ditampakkan dalam bentuk perilaku yang sesuai.

Menurut Freud konasi merupakan wujud dari kognisi dan afeksi dalam bentuk tingkah laku. Jadi, dapat disimpulkan bahwa komponen sikap mencakup tiga aspek yaitu: komponen kognitif, afektif dan konatif. Komponen kognitif berupa pemahaman, pengetahuan, pandangan dan keyakinan seseorang terhadap objek sikap.

Komunikasi merupakan hal yang mengikat kesatuan organisasi. Komunikasi membantu anggota anggota organisasi mencapai tujuan Individu dan organisasi, merespon dan mengimplentasikan perubahan organisasi, mengkoordinasikan aktivitas organisasi, dan ikut memerankan dalam hampir semua tindakan organisasi yang relevan. Meskipun demikian berkomunikasi dengan baik tidaklah mudah.

Organisasi yang memiliki proses komunikasi yang baik tentunya akan terus berkembang dan memiliki peraturan seperti nilai nilai, asumsi dasar yang merupakan budaya organisasi

Strategi komunikasi yang tepat dibutuhkan dalam upaya membangun budaya K3 Mintzberg, berpendapat bahwa strategi berkaitan dengan 4 (empat) hal, yaitu: 1). Strategy as a plan merupakan suatu rencana yang menjadi pedoman bagi organisasi untuk mencapai sasaran dan tujuan yang telah ditetapkan, 2). Strategy as a pattern. Strategi merupakan pola tindakan konsisten yang dijalankan organisasi dalam jangka waktu yang lama, 3). Strategy as a position. Strategi merupakan cara organisasi dalam menempatkan produk dan jasa tertentu dalam pasar yang spesifik, 4). Stategy as a perspective. Strategi merupakan cara pandang organisasi dalam menjalankan berbagai Kebijakan yang berkaitan dengan Visi, Misi dan budaya organisasi

Menurut Effendy strategi komunikasi merupakan paduan perencanaan komunikasi dengan manajemen komunikasi untuk mencapai tujuan yang telah ditetapkan, yaitu: 1) To secure understanding. memastikan bahwa komunikan mengerti pesan yang diterimanya, 2) To establish acceptance, sudah dimengerti dan dipahami penerimaannya maka harus dibina, 3) To motivate action, pada akhirnya kegiatan dimotivasikan. 
Submitted: 5 Nopember 2019; Revised: 18 Nopember 2019; Accepted: 3 Desember 2019; Published: 25 Januari 2020

Sayoga, berpendapat beberapa prinsip yang perlu diperhatikan dalam merencanakan komunikasi, yaitu: 1). Rencana merupakan patoka Bersama sehingga harus mencerminkan aspirasibersama (bukan keputusan perorangan / pribadi), 2). Implementasi rencana biasanya melibatkan masyarakat, oleh karena itupenting sekali mendengarkan dan mempertimbangkan aspirasi masyarakat (bottom up) dan bersifat partisipatif, 3). Rencana yang disusun harus bersifat fleksibel, sehingga memudahkan bila terjadi perubahan / revisi dan penyesuaian, 4). Rencana komunikasi harus disusun secara jelas dan konkrit yang didalamnya harus mengandung "what to do ", dan "How to do "yang jelas dan pasti agar tidak menimbulkan salah persepsi dan penafsiran

Sayoga juga mengatakan bahwa perencanaan komunikasi meliputi: Pengumpulan data baseline \& need asssesment, penetapan tujuan komunikasi, analis dan segmentasi khalayak, pemilihan media, mendesain dan mengembangkan pesan, perencanaan pengelolaan pelaksanaan program dan pelatihan pada komunikator.

Komunikasi memegang peranan vital dalam sebuah organisasi yang dalam kenyataannya masalah komunikasi akan selalu muncul dalam proses berorganisasi dan komunikasi organisasi menjadi sistem aliran yang menghubungkan dan membangkitkan/ meningkatkan kinerja antar fungsi / bagian dalam organisasi sehingga menghasilkan sinergi dan tujuan organisasi dapat tercapai. Menurut Redding dan Sanborn adalah pengiriman dan pengiriman dan penerimaan berbagai pesan didalam organisasi, dalam kelompok formal maupun informal organisasi

Komunikasi organisasi merupakan konteks yang kompleks. Romli mengatakan bahwa terdapat dimensi dalam arus komunikasi yang terjadi dalam sebuah organisasi, yaitu: 1) Komunikasi Internal, adalah proses penyampaian pesan antara anggota anggota organisasi yang untuk kepentingan organisasi seperti komunikasi antara pimpinan dan bawahan, antara sesama bawahan, dan sebagainya. 2) Komunikasi eksternal, adalah komunikasi antara organisasi dengan khalayak diluar organisasi. Pada komunikasi Eksternal terdapat dua jalur komunikasi secara timbal balik (dua arah).

\section{Metode Penelitian}

Dalam penelitian sering sekali peneliti berhubungan dengan data, baik itu penelitian yang berhubungan dengan lapangan ataupun penelitian lainnya.

Teknik/Metode Pengumpulan Data yang dilakukan adalah: a). Observasi adalah dengan cara pengamatan langsung terhadap aktivitas Pekerja P.T X berikut lingkungan fisiknya dan atau suatu kegiatan tanpa mengganggu proses yang sedang berjalan. b). Wawancara dengan menggunakan Daftar Pertanyaan (kuisioner). Daftar pertanyaan (kuisioner) yang berisi pertanyaan-pertanyaan untuk tujuan khusus yang memungkinkan seorang analis system untuk mengumpulkan data dan pendapat dari para responden yang telah dipilih. jawaban atau respon dari responden secukupnya. 
Dokumentasi menggunakan dokumentasi perusahaan sebagai sumber data berupa data tertulis (Forum Komet, papan informasi K3, Rapat manajemen, Tinjauan Manajemen, majalah dan buletin, leaflet, rapat rapat $\mathrm{K} 3$, laporan yang dapat menunjang penelitian ini).

Studi kepustakaan, yaitu mempelajari referensi buku-buku yang berkaitan dengan penelitian.

\section{Hasil dan Pembahasan}

PT. X memiliki komitmen untuk melakukan komunikasi aspek K3 secara transparan. Komunikasi dianggap sebagai alat penting untuk meningkatkan kesadaran dan kinerja K3, maka dari itu Komunikasi Internal disampaikan secara intensif (komunikasi dua arah) dari dan ke seluruh pekerja dan mitra kerja, keluarga ndan stakeholder dengan media yang telah ditentukan

Begitu juga komunikasi external adalah dasar pelaksanaannya dengan Kebijakan HSSE PT. Xyang membina baik hubungan dengan stake holder,dan harus memperhatikan: penyampaian informasi aspek K3 pada terjadinya insiden yang tingkat keparahannya mencapai katagori berat, kejadian atau insiden yang sedang dalam penyelidikan, tuntutan hukum dan persidangan pengadilan.

PEKA Observasi adalah metode pengamatan sekaligus dialog dari seseorang kepada orang lain bisa pekerja, kontraktor, tkjp dari level atas dan bawah.

Dalam PEKA observasi ini, pengamat tidak hanya mencari temuan namun juga melakukan penguatan aspek budaya bagi orang / responden yang sedang diamati.

Dalam PEKA observasi ini, pengamat harus melakukan dialog sesuai dengan kaidah dialog aspek HSE yang tidak menggurui dan tidak menyalahkan. Dialog dilakukan secara kekeluargaan, tenang, dan terbuka. Namun dialog ini menghasilkan konklusi budaya HSE yang akan diterapkan oleh observee setelah observee menyadari bahwa budaya perilaku yang dia lakukan adalah salah. Observe diajak untuk menyadari sendiri perilaku salahnya kemudian diajak untuk menciptakan perilaku positif yang sama sekali tidak di drive oleh observer. Jadi munculnya kesadaran bukan karena dorongan observer melainkan berdasarkan kesadaran yang tumbuh dari observe.

Kegiatan observasi ini di PT. X diterapkan dari level asisten manajer kepada bawahannya. Diharapkanpimpinan setempat dapat menjadi contoh dalam implementasi aspek HSE.

Kegiatan ini dilakukan secara terus-menerus dan dilaporkan secara periodik untuk memastikan ada perbaikan level budaya. Dari laporan tersebut di analisis at risk behavior mana sajakah yang harus menjadi fokus perusahaan untuk ditindaklanjuti.Dari data tersebut akan dibuat program peningkatan kualitas budaya aspek HSE di perusahaan. Kualitas budaya khas yang meningkat adalah semakin dipahaminya pentingnya aspek HSE secara internal orangan bukan hanya karena aspek punishment yang diberikan oleh perusahaan atas pelanggaran yang terjadi. 
Submitted: 5 Nopember 2019; Revised: 18 Nopember 2019; Accepted: 3 Desember 2019; Published: 25 Januari 2020

Diharapkan setiap personil tidak hanya peduli pada keselamatan dirinya tapi juga peduli pada keselamatan teman-teman dan orang-orang yang ada disekitarnya. diharapkan setiap orang yang melaksanakan atau mematuhi peraturan HSE bukan karena karena adanya peraturan yang mengikat tapi lebih dikarenakan setiap orang merasa perlu untuk melakukannya atas kesadaran pada internal diri seseorang.

PT. X mempunyai komitmen tinggi terhadap PEKA , yang bertujuan untuk: Memonitor \& memperbaiki perilaku, Memberikan penghargaan pada perilaku posistif, Memperbaiki perlaku tidak aman, Menciptakan dialog terkait perilaku aman \& yang tidak aman ,Mampu memprioritaskan observasi berdasarkan tingkat risiko, Mampu menentukan tindakan koreksi atas hasil pengamatan, atau jika ada: Prosedur baru, pekerja baru, peralatan baru, perubahan peralatan

Memberikan apa yang harus dilakukan dilakukan kepada para pekerja PT.X. seperti : Ciptakan diskusi yang relaks,Bebaskan subordinat menceritakan pekerjaannya,Bersikaplah sebagai keluarga, bukan atasan,Buat agar subordinat menyadari keslahannya sendiri,Buat kesepakatan antara Anda \& Subordinat agar melakukan safe action, Berikan reward jika subordinat melakukan safe action.

Hasil Pengamatan terlihat pada Gambar 1 berikut ini:

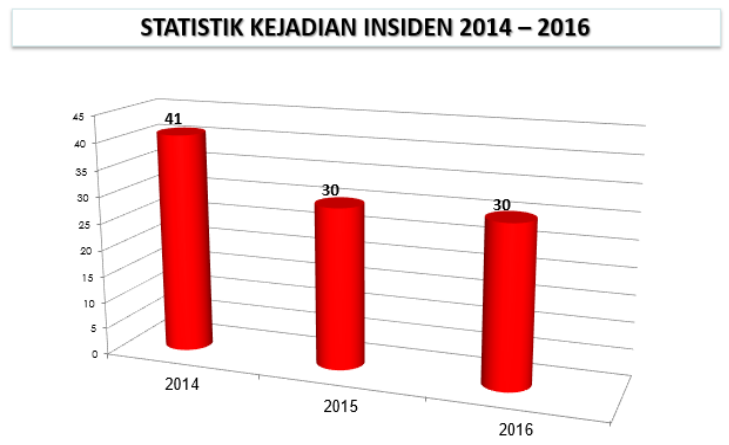

Sumber: Hasil Pengolahan Data (2020)

Gambar 1. Hasil Pengamatan

Dari Gambar 1. data statistik insiden di tahun 2014 terdapat = 42 kejadian, ditahun 2015 dan 2016 cenderung menurun menjadi $=30$ kejadian

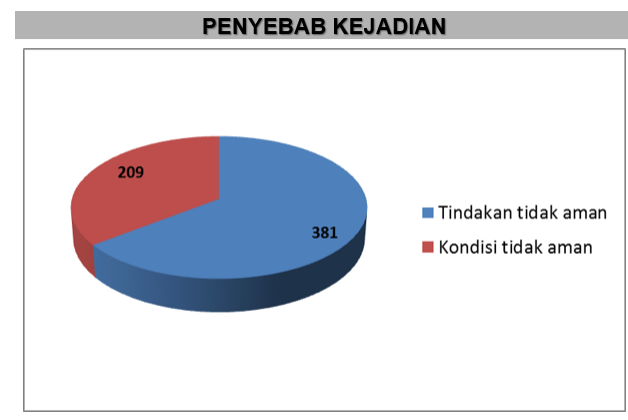

Sumber: Hasil Pengolahan Data (2020)

Gambar 2. Penyebab Kejadian 
Dilihat dari Gambar 2 Penyebab kejadian: a) Tindakan tidak aman (unsafe act) terdapat 209 kejadian $=35 \%$, dan b) Kondisi tidak aman (unsafe condition) terdapat 381 kejadian = $65 \%$

Dari Data Primer dan Data sekunder Hasil Evaluasi observasi PEKA sebagai berikut: 1). Bahwa pekerja menyadari akan pentingnya membentuk suatu budaya safety sehingga PEKA (Pengamatan Keselamatan Kerja) menjadi salah satu program untuk menciptakan budaya safety tersebut. Tahapan PEKA dan tujuan PEKA sangat penting untuk disosialisasikan kepada pekerja sehingga sosialisasi sangat perlu untuk dilaksanakan. Dimana sosialisasi untuk meningkatkan kepedulian pekerja dalam hal aspek K3LL / HSE. 2). Analisis Faktor Penguat adalah Pedoman Komunikasi dan Promosi HSSE, Pedoman SMK3 dan Prosedur PEKA PT. $X$, 3) Hasil wawancara mendalam (depth interview) terhadap informan/responden utama dan reward terhadap pelaksanaan PEKA didapatkan bahwa reward sudah diberikan kepada pengisi PEKA, namun punishment belum maksimal diterapkan terhadap pelaku unsafe condition, unsafe act, dan near miss. Alasan mengenai diberikannya punishment dan reward untuk memotivasi pekerja agar senantiasa berperilaku aman dan mengkondisikan lingkungan kerja yang aman serta dapat menambah minat untuk melakukan pengisian PEKA, 4) Analisis Hasil Obervasi Pelaksanaan PEKA yaitu didapatkan: a) Tindakan fungsi lain untuk mengatasi temuan temuan baik unsafe act (Tindakan tidak aman) unsafe condition (Kondisi tidak aman) maupun nearmiss (hampir celaka) sudah diterapkan dengan baik, sehingga pelaksanaan PEKA berjalan dengan baik, b) Komunikasi antara bagian/fungsi lain sudah berkoordinasi dengan baik karena menjadi faktor utama untuk tindak lanjut hasil temuan observasi PEKA, sehingga pekerja bertambah tinggi kepercayaan terhadap PEKA. c) Sosialisasi PEKA diberikan sewaktu waktu pada saat kegiatan kegiatan seperti Safety Induction, Safety Talk, Safety Breifing, dan Pelatihan.

\section{Kesimpulan}

Dari hasil Observasi Pengamatan Keselamatan Kerja (PEKA) adalah observasi dan koreksi keselamatan kerja terhadap tindakan dan/atau kondisi tidak aman di lokasi kerja yang dilakukan oleh pekerja PT. X dan Mitra Kerjanya, penulis dapat menyimpulkan sebagai berikut: 1). Dari Penyebab kejadian terlihat: a). Tindakan tidak aman (unsafe act) terdapat 209 kejadian $=35 \%$. b) Kondisi tidak aman (unsafe condition) terdapat 381 kejadian $=65 \%, 2$ ) Dari data statistik insiden terlihat: di tahun 2014 terdapat $=42$ kejadian ditahun 2015 dan 2016 cenderung menurun menjadi $=30$ kejadian. 3 ). Beberapa hal yang dilaksanakan oleh PT. X untuk meningkatan dalam membangun Budaya K3 yang sudah diterapkan dengan baik adalah: a) Apabila temuan observasi PEKA kategori berat, dibahas didalam rapat Komite HSSE, baru kemudian dilakukan tindak lanjut, b) Memberikan tindakan langsung apabila diperlukan, mengisi formulir dan memasukkan ke PEKA Box, kemudian input / memasukkan ke PEKA online, c) Pelaksanaan PEKA sudah berjalan dengan baik di PT.X, hal ini dibuktikan bahwa Pengelolaan 
Submitted: 5 Nopember 2019; Revised: 18 Nopember 2019; Accepted: 3 Desember 2019; Published: 25 Januari 2020

Implementasi PEKA sudah berjalan dengan lancar untuk memproses tindak lanjut temuan observasi PEKA yang dilanjutkan ke fungsi / bagian lain serta terlihat dari data statistik ada penurunan jumlah kejadian, d) Sosialisasi PEKA sudah dilakukan secara merata keseluruh pekerja Tindakan fungsi / bagian lain yang cepat untuk mengatasi suatu temuan juga sudah dilaksanakan dengan baik, karena area / lapangan memiliki risiko tinggi. PT. X berdasarkan Target Pencapaian dalam membentuk Budaya K3 dengan terus membangun budaya K3 untuk mencapai tingkatan budaya mulai dari proaktif ke generatif, dilakukan secara bertahap dengan waktu jangka pendek dan jangka panjang. Dengan dicapainya budaya K3 generatif sekaligus menandakan tercapainya tujuan utama (goal) PT.X secara umum, yaitu menjadi World Class Company dan melaksanakan operasionalnya dengan minimalisasi insiden kecelakaan, kebakaran, blow out (semburan liar), penyakit akibat kerja maupun pencemaran lingkungan.

\section{Daftar Pustaka}

Ronda, A.M. (2018). Tafsir Kontemporer Ilmu Komunikasi (Tinjauan Teoretis, Epistemologi, Aksoilogi. Tangerang: Indigo Media.

Craig, R.T, \& Muller, H.L. (2007). Theorizing Communication. USA, Sage Publications, Inc.

Depkes RI. (2009). Profil Kesehatan Indonesia.Jakarta: Departemen Republik Indonesia.

Ginting. (2013). Perubahan Budaya Safety di Industri. Jakarta: World Class Quality Management.

Gunawan. (2013). Safety Leadership. Jakarta: Dian Rakyat

Kriyantono, R. (2006). Teknik Praktis Riset Komunikasi. Jakarta: Kencana.

Liliweri, A. (2018). ParadigmaPenelitianllmu Sosial. Yogyakarta: Pustaka Pelajar.

Littlejohn, \& Stephen W. (2009). Teori Komunikasi. Jakarta: Salemba Humanika.

Peraturan Pemerintah Republik Indonesia no 50, tahun 2012 tentang Penerapan Sistem Manajemen Keselamatan, Kesehatan Kerja (SMK3)

Soehatman, R. (2010). Pedoman Praktis Manajemen Risiko Dalam Persfektif K3, OHS Risk Management. Jakarta: Dian Rakyat.

Suma'mur. (1989). Keselamatan Kerja dan Pencegahan Kecelakaan Kerja. Jakarta: Gunung Agung.

Neuman, W.L. (2013). Metodologi Penelitian Sosial: Pendekatan Kualitatif dan Kuantitatif, Edisi 7, Boston, MA02116.

Ginting. (2013). PerubahanBudaya Safety di Industri. Jakarta: World Class Quality Management Gunawan. (2013). Safety Leadership. Jakarta: Dian Rakyat.

Effendy, O.U. (2003). IImu Komunikasi Teori dan praktek Bandung, PT. Remaja Rosdakarya. Konradus, D. (2006). Keselamatan Kesehatan Kerja. Jakarta: Bangka Adhinata Mulia.

Ramli, S. (2010). Manajemen Keselamatan Proses Berbasis Risiko Jakarta: Dian Rakyat. 